\title{
INOVASI PROGRAM BANK SAMPAH MELALUI PEMBERDAYAAN MASYARAKAT SEBAGAI PROSES KOMUNIKASI PERUBAHAN SOSIAL
}

\author{
Hilman Ramayadi', Nopita Sariningsih ${ }^{2}$ \\ Universitas Diponegoro, 2Universitas Sultan Ageng Tirtayasa
}

\begin{abstract}
Waste management is essentially needed by the community in Lebak Regency to reduce waste buildup. The concept of trash bank as a solution in order to change the paradigm of society in waste management is a new innovation for peoples in kabupaten lebak. There fore in this research, the researcher want to explain and study the communication process carried out by the management of the Barangbang Garbage Bank and how to adopt the innovation of the garbage bank program by the community in East Muara Ciujung Village, Lebak Regency. This study uses descriptive qualitative research methods. The results showed that the communication process carried out by the management of the Sampang Barangbang Bank was more about installing communication channels using print media, spatial planning and face-to-face communication. The results of the research show that the communication process carried out by the Barangbang Garbage Bank management more emphasis on the communication channel stage through the use of print media, spatial planning and face-to-face communication.
\end{abstract}

\section{Keywords}

Adoption of Innovation, Waste Bank Programs, Community Empowerment, Communication Process.

Correspondence Contact ramayadihilman@gmail.com nopitasari@gmail.com

\section{PENDAHULUAN}

Dewasa ini isu lingkungan merupakan bagian penting dari sebuah penelitian di abad ke-21. Isu permasalahan lingkungan hidup kini bukan hanya menjadi isu nasional, melainkan sudah menjadi tugas bagi semua negara untuk berperan serta dalam memperbaiki dan menjaganya. Tuntutan kebutuhan hidup yang besar membuat manusia mengesampingkan mengenai dampak lingkungannya. Seperti hal nya masalah penumpukan sampah di Indonesia jika setiap orang dirata-ratakan memproduksi sampah sebanyak $0,7 \mathrm{~kg}$ per orang per hari, dapat ditotalkan sebanyak 175 ribu ton per hari produksi sampah yang dihasilkan secara nasional atau dalam setahun sebanyak 64 juta ton per tahun. Dari seluruh jumlah tersebut, didominasi oleh sampah non-organik seperti plastik (Fatah, 2019). Sama seperti di daerah lain di Indonesia, Kabupaten Lebak Provinsi Banten. Sampah masih menjadi permasalahan dengan penanganan masih lemah. Dengan jumlah penduduk sebanyak 1.305 .430 jiwa. Sedangkan produksi sampah yang dihasilkan perhari sebanyak 3.030,99 m3. Tertangani atau terangkut ke Tempat Pembuangan Akhir hanya sebesar $396 \mathrm{~m} 3$ per hari atau dalam persentase $(12,96 \%)$ dari total keseluruhan. Sedangkan 2.659,17 m3 atau $(87,04 \%)$ sampah yang masih tersisa atau belum terangkut ke Tempat Pembuangan Akhir (BAPPEDA, 2014). Statistik perkembangan pembangunan Bank Sampah di Indonesia tahun 2017, keberadaan Bank Sampah saat ini sudah tersebar di 34 Provinsi atau 219 kota/kabupaten di Indonesia dengan total keseluruhan sebanyak 5.244 Bank Sampah (BPS, 2018). Social engineering masih menjadi sistem pengembangan Bank Sampah dengan tujuan menumbuhkan kesadaran masyarakat dalam0pengelolaan sampah secara bijak0dan pada hasilnya akan mengurangi sampah yang diangkut ke TPA1dengan cara memilah sampah8 sebelumnya (KLH, 2012).

Masalah lain yang terjadi dalam sebuah proyek atau action plan terkait kebijakan lingkungan sering terjadi solusi atau inovasi yang ditawarkan tidak sepenuhnya dimiliki, diterima, dan 
digunakan oleh masyarakat. Oleh karena itu diperlukan komunikasi dua arah untuk menghasilkan interaksi antara pembuat kebijakan dengan masyarakat dan sebaliknya. Kondisi yang diharapkan adalah terciptanya win-win situations. Hal ini dirasa penting mengingat suatu kebijakan mengenai isu lingkungan tidak selesai pada tahapan didengar, dimengerti, maupun diterima oleh masyarakat, tetapi harus sampai pada tahapan dilakukan. Inovasi akan menarik perhatian apabila terdapat kesamaan kesesuaian, manfaat tepat guna, kemudahan dalam mencoba, dampak yang besar dan mudah diaplikasikan akan lebih cepat diadopsi (Febriana \& Setiawan, 2016). Hal ini selaras dengan hasil penelitian sebelumnya bahwa Pengelolaan Bank 9Sampah Alam Lestari di Kota Serang9Provinsi Banten dengan mengaplikasikan difusi inovasi melalui pemberdayaan masyarakat dianggap berhasil. Secara umum proses inovasi yang dilakukan oleh bank sampah Alam Lestari pada awalnya berjalan lambat dan mendapat respon negatif berupa anggapan sebagai pemulung, jorok dan sebagainya, namun lambat laun akhirnya hampir semua masyarakat Desa Lontar Baru menerima keberadaan program dan inovasi bank sampah (Sucahya \& Surahman, 2017).

Memunculkan isu-isu maupun solusi/inovasi yang ditawarkan9untuk kepermukaan sehingga diketahui oleh masyarakat, komunikasi menjadi bagian penting guna melihat serta menjembatani permasalahan ini. Konsep bank sampah sebagai solusi dalam merubah paradigma masyarakat dan memberikan pengetahuan baru dalam penanganan sampah ini merupakan inovasi baru bagi masyarakat di Kabupaten Lebak. Oleh sebab itu dalam penelitian ini, fenomena masuknya inovasi baru ke dalam masyarakat dikategorikan dalam teori difusi inovasi. Teori ini melibatkan aspek-aspek komunikasi yang penting untuk memperoleh keberhasilan dalam menyebarkan atau menanamkan inovasi dalam benak masyarakat, seperti pesan yang berupa ilmu pengetahuan atau informasi, media penyebaran informasi, siapa yang menyampaikan, dan apa efek informasi mengenai inovasi tersebut kepada masyarakat. Sehingga, dalam proses interaksi antara organisasi dan masyarakat, terdapat proses komunikasi yang dapat dianalisis (Nasution, 2002). Keterkaitan difusi inovasi bank sampah dengan proses komunikasi sangat dibutuhkan dalam perencanaan sosial. Strategi dalam mensukseskan pengelolaan bank sampah meliputi: edukasi masyarakat di awal pembentukan, proses pengumpulan, pemilahan menurut kategori masing-masing, penjualan dan pembelanjaan uang sampah sesuai kebutuhan (Purwanto, 2019).

Studi difusi mengonseptualisasikan, menginformasikan dan menjabarkan lima tahapan dalam proses adopsi individu yaitu tahap pengetahuan, tahap bujukan, tahap putusan, tahap implementasi dan tahap konfirmasi (Nasution, 2002). Dengan melaksanan tahapan difusi inovasi diharapkan mendapat strategi pemberdayaan yang dapat diterima. artinya bahwa dalam sebuah program, setiap keputusan tindakan jangka pendek harus mendukung sasaran jangka panjang yang strategis (Shahreza, 2018).

Bank Sampah di Kabupaten Lebak pertama kali digagas oleh masyarakat kampung Barangbang, Kelurahan Muara Ciujung Timur. Berdasarkan hasil pra observasi, Ketua Bank Sampah Barangbang Nunu Rahmat Nugraha, beralasan dibentuknya Bank Sampah ini melihat kebiasaan dan kesadaran masyarakat dalam membuang sampah masih kurang. Sampah selalu diposisikan menumpuk dibelakang rumah, lalu dibakar, bahkan hasil akhir dengan dibuang ke sungai. Pola perilaku masyarakat dalam membuang sampah seperti itu dianggap tidak menjadi masalah karena masyarakat beralasan dampak yang dirasakan dari caranya tersebut tidak ada timbal balik yang signifikan pada dirinya secara langsung. Metode pengelolaan sampah di masyarakat saat ini masih didominasi dengan sistem sampah dikumpulkan terlebih dahulu,0lalu diangkut kemudian proses akhir dibuang ke lahan tertentu atau sering disebut0dengan sistem kumpul angkut. Tujuan lainnya yaitu meningkatkan pengetahuan masyarakat tentang kepedulian terhadap permasalahan lingkungan. Paradigma manusia yang semula setiap hari memproduksi sampah, diharapkan beralih menjadi manusia yang 
mengolah dan memberikan nilai tambah terhadap sampah yang telah diproduksi. Hal tersebut sejalan dengan Undang-Undang Nomor 18 tahun 2008 tentang Pengelolaan Sampah, yang menjelaskan tentang prinsip dalam pengelolaan sampah yaitu dengan cara mengurangi, menggunakan kembali dan mengolah atau mendaur ulang.

Pendekatan yang dilakukan dalam kegiatan bank sampah Barangbang dengan pola pendekatan melalui pemberdayaan masyarakat. Ada dua kegiatan penting yang diberikan oleh Bank0Sampah Barangbang dalam program pemberdayaan yaitu meningkatkan pengetahuan (knowledge) dan keterampilan (skill). Peningkatan dilakukan dengan memberikan pendidikan berwawasan lingkungan dan pengembangan usaha Bank Sampah, sedangkan peningkatan keterampilan dilakukan dengan memberikan bekal keahlian secara teknis. Untuk dapat digunakan dan diterima, sebuah inovasi harus disebarkan dengan cara mengkomunikasikan kepada masyarakat luas. Agar bisa mengakomodir keberagaman sosial, ekonomi, budaya dan faktor agama serta gender komunikasi yang bersifat partisipatif menjadi cara dalam program pemberdayaan masyarakat. Hal ini dibuktikan hasil penelitian (Satriani, Muljono, \& Lumintan, 2011) bahwa setiap kegiatan masyarakat dengan pendekatan komunikasi partisipatif sangat bermanfaat dengan saling berbagi informasi dan pengetahuan, penyelesaian masalah diselesaikan secara bersama serta terjalinnya keakraban sesama. Pada dasarnya konsep partisipasi adalah membangkitkan setiap warga untuk terjun dalam pembangunan negara, yang artinya maju atau tidaknya pembangunan tergantung dari peranan masyarakat itu sendiri (Ahmad, 2016).

Bentuk komunikasi yang digunakan dalam penyebaran inovasi kegiatan bank sampah yaitu melalui tatap muka dengan masyarakat dan sekolah-sekolah yang ada di Kelurahan Muara Ciujung Timur, kemudian dengan menyebarkan informasi melalui opinion leader, dan menggunakan media massa seperti media cetak dan menggunakan media luar ruang (spanduk, leaflet, dan pamflet). Penggunaan opinion leader dilakukan dengan mengumpulkan RT/RW dan Lurah untuk menggerakkan masyarakat agar peduli lingkungan dan mengubah kebiasaan mereka dalam mengelola sampah.

Sehubungan dengan latar belakang penelitian diatas, peneliti tertarik untuk mengkaji lebih dalam mengenai bagaimana pengurus Bank Sampah Barangbang mengkomunikasikan inovasi kegiatan pengelolaan sampah kepada masyarakat Kelurahan Maura Ciujung Timur dan bagaimana masyarakat Kelurahan Maura Ciujung Timur menerima inovasi baru tentang pengelolaan sampah dengan berpartisipasi dan mengadopsi inovasi tersebut.

\section{KAJIAN TEORITIK}

\section{Komunikasi Perubahan Sosial}

Perubahan sosial ialah proses sosial yang dialami oleh anggota masyarakat dalam tingkat0kehidupan masyarakat secara sukarela atau dipengaruhi oleh unsur-unsur eksternal meninggalkan pola-pola kehidupan, budaya, sistem, sosial lama kemudian menyesuaikan diri atau menggunakan pola-pola kehidupan, budaya, dan sistem sosial yang baru serta semua unsur-unsur budaya dan sistem-sistem sosial (Bungin, 2008). Dalam hubungannya dengan proses sosial, komunikasi menjadi sebuah cara dalam melakukan perubahan sosial. Komunikasi berperan menjembatani perbedaan dalam masyarakat karena mampu merekatkan kembali sistem sosial masyarakat dalam usahannya melakukan perubahan.

\section{Komunikasi dan Difusi Inovasi}

Berbicara mengenai komunikasi, tentunya akan terkait pada salah satu teori penting untuk memahami itu, yaitu; "Teori Difusi Inovasi". Teori difusi inovasi pertama kali dikenalkan oleh 
Everett M. Rogers. Teori ini menjelaskan proses bagaimana satu inovasi disampaikan (dikomunikasikan) melalui saluran komunikasi tertentu sepanjang waktu di antara anggotaanggota sistem sosial (Rogers, 2003). Tujuan dari teori difusi inovasi ini adalah diadopsinya suatu inovasi pemberdayaan masyarakat dalam pengelolaan bank sampah oleh anggotaanggota sistem sosial. Proses komunikasi dalam difusi inovasi bersifat konvergen diantara dua orang atau lebih yang bertukar informasi. Karena sifatnya dua arah maka memungkinkan untuk masing-masing partisipan menciptakan dan berbagi informasi agar tercapai kesamaan persepsi, pemahaman atau pengertian. Dengan adanya kesamaan pengertian inilah diharapkan inovasi tersebut akan diadopsi, meskipun pada akhirnya semua inovasi belum tentu diakhiri dengan proses adopsi.

Menurut Rogers, elemen-elemen utama dalam analisis suatu difusi inovasi adalah: (1) inovasi adalah gagasan-gagasan yang dianggap baru oleh penerima (2) dikomunikasikan melalui saluran-saluran tertentu (3) diantara anggota-anggota sistem sosial (4) secara terus menerus. Studi-studi difusi mengonseptualisasikan, menginformasikan dan menjabarkan empat tahapan dalam proses adopsi individu yaitu tahap pengetahuan, tahap bujukan/persuasi, tahap putusan, dan tahap implementasi (Rogers, 2003).

\section{Pemberdayaan Masyarakat}

Upaya untuk memampukan dan memandirikan masyarakat yang dilakukan dengan menciptakan suasana atau iklim yang memungkinkan potensi masyarakat berkembang, meningkatkan kapasitas dengan memperkuat potensi atau daya yang dimiliki oleh masyarakat, dan melindungi kepentingan dengan mengembangkan sistem perlindungan bagi masyarakat yang menjadi subjek pengembangan0 (Fahrudin, 2012). Tujuan yang ingin dicapai dari pemberdayaan adalah perbaikan kelembagaan, perbaikan usaha, perbaikan perbaikan pendapatan, perbaikan lingkungan, perbaikan kehidupan dan yang terakhir perbaikan masyarakat (Mardikanto, 2014). 0Kemandirian masyarakat merupakan suatu kondisi yang dialami oleh masyarakat yang ditandai oleh kemampuan untuk memikirkan, memutuskan serta melakukan sesuatu yang dipandang tepat demi mencapai pemecahan masalah-masalah yang dihadapi dengan mempergunakan daya kemampuan yang terdiri atas kemampuan kognitif, konatif, pikomotorik,0afektif, dengan pengerahan sumberdaya yang dimiliki oleh lingkungan internal masyarakat tersebut (Sulistyani \& Teguh, 2004).

\section{Sampah dan Pengelolaannya}

Menurut UU No 18 Tahun 2008 tentang Pengelolaan Sampah, Sampah adalah sisa kegiatan sehari-hari manusia atau proses alam yang berbentuk padat atau semi padat berupa zat organik atau anorganik bersifat dapat terurai atau tidak dapat terurai yang dianggap sudah tidak berguna lagi dan dibuang ke lingkungan. Jenis sampah yang ada di sekitar kita cukup beraneka ragam, ada yang berupa sampah rumah tangga, sampah industri, sampah pasar, sampah rumah sakit, sampah pertanian, sampah perkebunan, sampah peternakan, sampah institusi/kantor/sekolah dan sebagainya. Berdasarkan asalnya, sampah padat dapat digolongkan menjadi 2 (dua) yaitu sampah organik dan anorganik. Salah satu upaya dalam mengatasi masalah persampahan di Indonesia, dilakukan melalui program 3R (Reduce, Reuse dan Recycle). Program tersebut merupakan alternative pengurangan sampah dalam skala luas dan dapat diaplikasikan dalam kehidupan sehari-hari. Reduce, adalah proses mengurangi sampah yang bisa dilaksanakan dengan cara membeli produk yang tahan lama atau dikemas dengan packing yang tidak beracun. Reuse, adalah kegiatan penggunaan kembali sampah secara langsung. Recycle, adalah mendaur ulang sampah untuk menjadi produk baru. 


\section{METODOLOGI}

Penelitian ini menggunakan metode deskriptif kualitatif, dimana penulis mendeskripsikan atau mengkonstruksi wawancara-wawancara mendalam terhadap subjek penelitian. Penelitian ini dilaksanakan di Sekertariat Bank Sampah Barangbang Jl. KRN, Kp. Barangbang, Kel. Muara Ciujung Timur, Kecamatan Rangkasbitung, Kabupaten Lebak. Banten selama 3 bulan. Subjek penelitian adalah pengurus beserta anggota bank sampah Barangbang dengan objek yang diteliti adalah sosialisasi program bank sampah yang nantinya akan dilihat pengaruh proses adopsi inovasi yang dilakukan oleh pengurus yang diberikan kepada anggotanya.

Penulis menggunakan paradigma konstruktivis sebagai dasar kerangka berpikir. Pengetahuan manusia adalah kontruksi yang dibangun dari proses kognisi dengan interaksinya dengan dunia obyek material (Satori \& Komariah, 2010). Analisis data yang digunakan adalah analisis data interaktif yang disampaikan oleh Huberman dan miles dimana terdapat tiga hal utama dalam analisis interaktif yakni, reduksi data, penyajian data dan penarikan kesimpulan/verifikasi (Miles, Huberman, \& Saldana, 2014) Untuk menguji validitas data dalam penelitian ini, Peneliti menggunakan triangulasi data untuk menguji kredibiltas dan keabsahan data yang dilakukan dengan cara mengecek data yang telah diperoleh melalui beberapa sumber dengan teknik pengumpulan data yang bermacam-macam. Hasil wawancara yang peniliti dapat dari informan mengenai inovasi bank sampah sebagai program pemberdayaan masyarakat tersebut kemudian dikroscek kembali dengan menggunakan metode dokumentasi dan hasil survei. Apabila perdapat perbedaan hasil maka peneliti akan mendiskusikannya lagi kepada member data untuk melihat mana yang dianggap benar atau memang semuanya benar yang disebabkan sudut pandang yang berbeda.

\section{HASIL DAN PEMBAHASAN}

Program Bank sampah dirasa akan jauh lebih efektif dengan melibatkan masyarakat. Hal ini dimaksudkan selain menanamkan pengetahuan dan kesadaran masyarakat terhadap lingkungan, mengubah sampah menjadi barang yang bernilai jual menjadi nilai plus dari kegiatan yang dilakukan. Difusi inovasi adalah proses sosial yang mengkomunikasikan informasi tentang ide baru yang dipandang secara subjektif (Febriana \& Setiawan, 2016). Makna inovasi dengan demikian perlahan-lahan berkembang menjadi sebuah peroses perubahan sosial. Dalam hal ini proses difusi inovasi menjadi yang dilakukan pengurus bank sampah untuk bisa menjaring sebanyak-banyaknya anggota masyarakat yang terlibat. pemanfaatan barang yang tadinya dianggap tidak bernilai menjadi bernilai ekonomi dianggap sebagai inovasi baru oleh masyarakat guna solusi atas pencemaran lingkungan sekitar. Saluran komunikasi menjadi elemen penting agar inovasi tersebut bisa tersampaikan kepada khalayak sasaran, penggunaan media luar ruang, media masa, dan keterlibatan orang yang berpengaruh di masyarakat menjadi berbagai cara yang telah dilakukan oleh pengurus bank sampah selain komunikasi tatap muka yang lebih diintensifkan agar masyarakat lebih paham dengan transfer pengetahuan, dan hasil akhirnya ialah keikut sertaan dalam kegiatan tersebut. Keseluruhan proses tersebut terangkum dalam lima tahapan adopsi individu yang dikonsepkan Rogers.

\section{Proses Difusi Inovasi Melalui Pemberdayaan Masyarakat}

Difusi merupakan suatu komunikasi yang berkaitan dengan penyebaran pesan-pesan dengan ide baru. Dalam pengelolaan bank sampah, proses difusi terjadi saat para pengurus mengkomunikasikan kepada masyarakat tentang pengelolaan sampah yang sudah melalui tahap pelilahan dan bisa digunakan kembali dapat dijadikan sebagai bahan kerajinan lain yang 
multi fungsi. Hal yang tidak mudah dalam mengubah pola pikir masyarakat yang menganggap sampah sebagai sesuatu yang sudah tidak berguna dan anggapan negatif sebagai pemulung.

Rogers menjabarkan konseptualisasi dalam proses difusi inovasi pada lima tahapan yaitu pengetahuan, bujukan/persuasi, putusan, implementasi, dan konfirmasi (Rogers, 2003).

Tahap Pengetahuan: pada tahap ini penyebaran informasi tentang inovasi baru, kesadaran individu akan membentuk pengertian inovasi yang yang diberikan dan tentang bagaimana inovasi tersebut berguna. Rogers menyebutkan terdapat tiga jenis pengetahuan yang dicari masyarakat pada tahap ini, yakni kesadaran tentang inovasi itu ada, pengetahuan tentang penggunaan inovasi, dan pengetahuan bagaaimana inovasi tersebut bekerja. Pada penyebaran pesan inovasi diawal Pengurus Bank Sampah Barangbang lebih memfokuskan pada kegiatan komunikasi tatap muka dan media luar ruang seperti leaflet dan spanduk. Dalam leaflet diterangkan program bank sampah secara terperinci. leaflet berisi penjelasan bank sampah, tujuan, manfaat, info tentang program kegiatan, bentuk kegiatannya seperti apa dan proses pemanfaatan dan penyortiran sampah. Masyarakat biasanya memiliki tendensi untuk mengingat apa yang mereka lihat dalam media tersebut sehingga mempengaruhi keputusan mereka terhadap pengetahuan baru dalam penanganan sampah. Komunikasi tatap muka dilakukan dengan pemberdayaan masyarakat dimana Bank Sampah Barangbang membuat pelatihan pengelolaan sampah baik di sekolah-sekolah maupun pada masyarakat di Kelurahan Muara Ciujung Timur. Hal tersebut diharapkan dapat mengetahui respon masyarakat terhadap program baru dalam pengelolaan sampah yang dilakukan Bank Sampah Barangbang.

Gambar 1: Spanduk Bank Sampah Barangbang dipasang di Pos Ronda Kelurahan Muara Ciujung Timur.

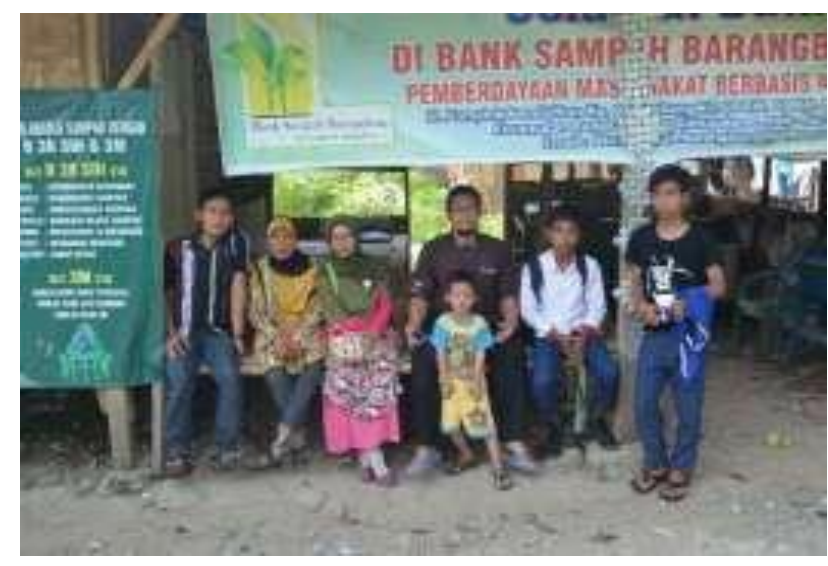

Sumber Gambar: Dokumentasi peneliti

Tahap bujukan/persuasi: individu akan membentuk sikap atau memiliki sifat menyetujui atau tidak menyetujui terhadap inovasi tersebut. Di tahap ini individu akan mencari lebih jauh tentang inovasi tersebut dan keuntungan mengadopsi inovasi tersebut. Diawal tidak mudah dalam menyebarkan inovasi yang sifatnya baru kepada masyarakat, pola pikir yang terbentuk sebelumnya membuat masyarakat enggan untuk mengadopsi inovasi tersebut. Maka bentuk komunikasi lain yang dilakukan adalah dengan penggunaan opinion leader. Adanya opinion leader selain dari pengurus Bank Sampah Barangbang, seperti RT/RW, Lurah, pihak Dinas Lingkungan Hidup Kabupaten Lebak dapat membantu dalam mempersuasi masyarakat untuk merubah pola pikir mereka dalam menjaga lingkungan yaitu dengan dilakukan sosialisasi- 
sosialisasi kepada masyarakat, sekolah-sekolah secara meluas untuk memberikan pemahaman dan kesadaran tehadap lingkungan. Seseorang yang relatif sering dapat mempengaruhi sikap dan tingkah laku orang lain untuk bertindak dengan cara tertentu secara informal dianggap sebagai pemuka pendapat. Guna mencapai tahap diimplementasikan oleh masyarakat dibuatlah skema kemanfaatan yang akan didapat setelah melakukan kegiatan tersebut. Tujuannya untuk menarik perhatian masyarakat dan meningkatkan kesadaran mereka terhadap lingkungan dengan bekerja sama antara Bank Sampah Barangbang, PDAM dan PLN sehingga hasil tabungan sampah masyarakat dapat dijadikan transaksi pembayaran air dan listrik. Selain itu hasil tabungan sampah tersebut dapat ditukarkan dengan kebutuhan pokok seperti sembako. Sedangkan untuk sekolah-sekolah hasil tabungan sampah tersebut masuk ke uang kas sekolah.

Gambar 2: Kegiatan Sosialisasi Bank Sampah Barangbang di Sekolah

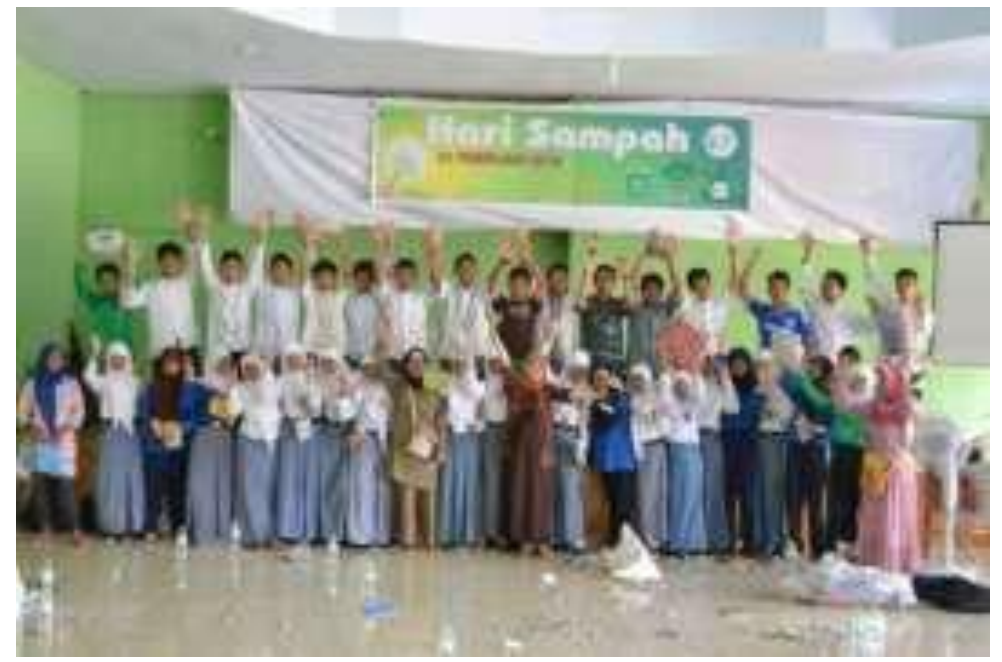

Sumber Gambar: Dokumentasi peneliti

Tahap keputusan: ditahap ini individu membawa pada suatu pilihan untu mengadopsi inovasi tersebut atau tidak. Adopsi adalah keputusan untuk menggunakan sepenuhnya ide baru sebagai cara tindak yang paling baik (Febriana \& Setiawan, 2016). Pada tahap ini masyarakat menyatakan telah menentukan untuk mengadopsi kegiatan pengeloaan sampah. Faktor yang mempengaruhinya adalah terjadi perubahan yang terjadi karena adanya Bank Sampah Barangbang ini lingkungan menjadi bersih, penumpukan sampah juga sedikit demi sedikit dapat teratasi. Hal lainnya yaitu terkait kebutuhan sendiri seperti menjadikan mereka lebih produktif dengan ikut dalam kegiatan pelatihan daur ulang sampah, hasil dari daur ulang sampah dan tabungan sampah tersebut dapat memberikan profit bagi mereka.

Dalam tahap keputusan ini, bila dikaitkan dengan kriteria penerima inovasi maka dapat disebut bahwa masyarakat ini termasuk dalam kategori mayoritas belakangan. Bila kategori adopter tersebut diterapkan pada proses adopsi inovasi program bank sampah di Kelurahan Muara Ciujung Timur, kategorinya adalah sebagai berikut: 
Tabel. 1 Kategori Adopter

\begin{tabular}{c|l|l} 
No & \multicolumn{1}{|c|}{ Kategori } & \multicolumn{1}{|c}{ Keterangan } \\
\hline 1 & Inovator & $\begin{array}{l}\text { Pengurus Bank Sampah Barangbang sebagai } \\
\text { penggagas kegiatan bank sampah }\end{array}$ \\
\hline 2 & Penerima Awal & $\begin{array}{l}\text { Sekolah-sekolah sebagai pemanfaat atau users } \\
\text { yang telah mengerti tentang bank sampah }\end{array}$ \\
\hline 3 & Mayoritas Belakangan & Masyarakat yang belum mengenal bank sampah \\
\hline 4 & Laggard & $\begin{array}{l}\text { Beberapa di antara mereka yang paling akhir } \\
\text { menerima sebuah inovasi. }\end{array}$ \\
\hline
\end{tabular}

\section{Sumber Data: Olahan Peneliti}

Tahap Implementasi: implementasi yang dimaksudkan ialah proses keterlibatan masyarakat terhadap program tersebut. Pada tahap ini masyarakat mengimplementasikan pengelolaan sampah untuk memenuhi berbagai kebutuhan mereka. Keputusan dalam penerimaan gagasan atau ide baru dibuktikan dengan praktek. Berdasarkan hasil observasi dan wawancara yang peneliti lakukan kepada narasumber, mereka telah mengelola sampah baik dengan menabung maupun dengan membuat hasil kerajinan daur ulang sampah. Hasilnya terdapat 76 nasabah yang ikut terlibat dalam tabungan sampah termasuk sekolah-sekolah.

Gambar 3: Hasil kerajinan daur ulang sampah

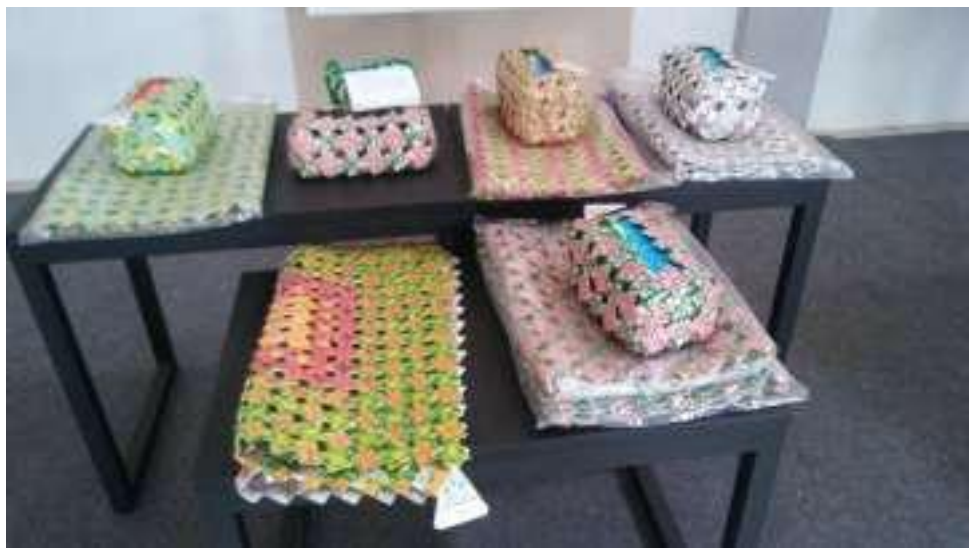

Sumber Gambar: Dokumentasi peneliti

Seperti yang dilakukan oleh Ibu Mamah Wahanimah, ia telah membuat kerajinan daur ulang sampah tersebut baik untuk kebutuhan pribadi maupun untuk dijual. Sampah-sampah yang diproduksi oleh ibu Mamah Wahanimah tersebut dikumpulkan di trash back, sampah tersebut kemudian dipilah lalu yang bisa ditabung ia tabungkan di Bank Sampah Barangbang, sampah seperti plastik bungkusan coffee, bekas kemasan ale-ale ia bersihkan untuk dibuat kerajinan daur ulang. Bukan hanya Mamah Wahanimah yang mempraktekan pengelolaan sampah tersebut, di sekolah MTSN 1 Lebak pun dipraktekan kepada murid-murid. Setiap kelasnya diberlakukan mengumpulkan sampah minimal setengah kg per harinya. Kemudian sampah 
tersebut dipilah. Sampah organik dibuat kompos, sampah plastik bekas kemasan ale-ale dibuat kerjinan sedangkan sisanya ditabungkan di Bank Sampah Barangbang.

Gambar 4. Pembuatan kerajinan dari plastik kemasan minuman

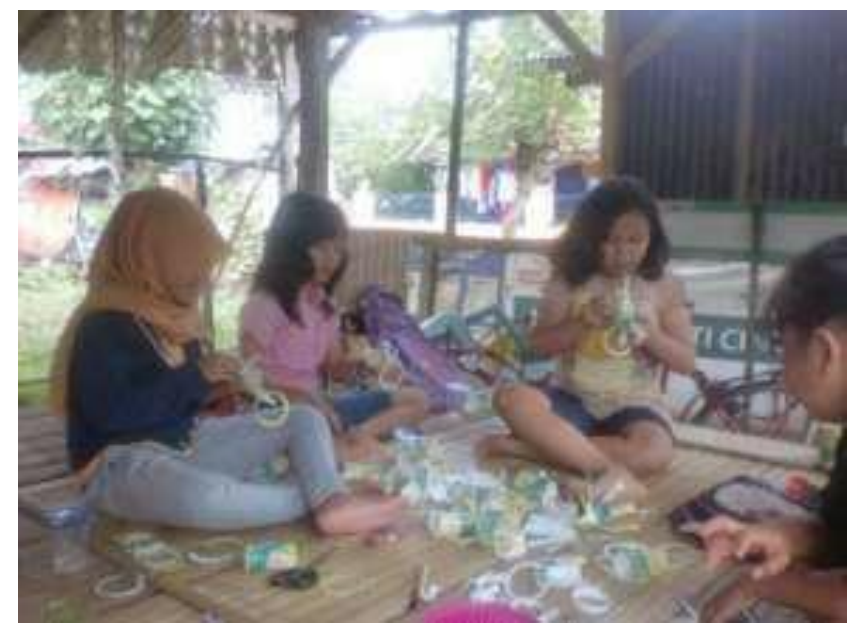

Sumber Gambar: Dokumentasi peneliti

Tahap terakhir konfirmasi: Dalam tahap ini masyarakat menyatakan kembali kesannya selama mengadopsi kegiatan pengelolaan sampah yang telah mereka lakukan. Sebagian besar merasakan bahwa Bank Sampah ini sudah dapat dirasakan keberadaannya meskipun masih belum memenuhi ekspektasi tapi setidaknya masyarakat sudah mengenal dan mengelola sampah dengan sendiri berkat bank sampah. Selain itu berdasarkan hasil obesrvasi dan wawancara, perubahan yang terjadi di Kelurahan Muara Ciujung Timur adalah adanya kegiatan Bank Sampah Barangbang ini sekarang sudah bisa mengurangi penumpukan sampah, memberikan pelatihan bagi masyarakat cara mengelola sampah dan dapat menghasilkan keuntungan.

Gambar 5. Pameran hasil daur ulang sampah berupa tempat tissue, keranjang belanja, pot bunga, hingga bingkai foto.

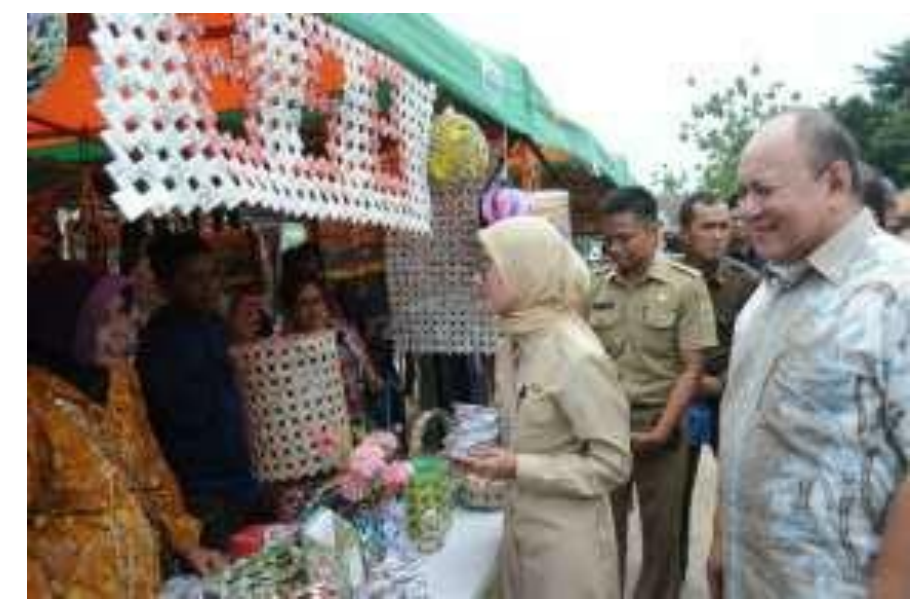

Sumber Gambar: Dokumentasi peneliti 
Setelah dirasa sesuai dan memberikan manfaat bukan hanya untuk kesadaran lingkungan saja mereka memutuskan untuk mengadopsi pogram pengelolaan sampah tersebut dengan ikut terlibat dalam tabungan sampah dan membuat kerajinan dari daur ulang sampah setelah mengikuti pemberdayaan masyarakat mengenai pelatihan daur ulang sampah yang dibuat kerajinan dan kompos. Dari keenam narasumber yang peneliti observasi dan wawancarai semuanya memutuskan untuk mengadopsi pengelolaan sampah. Tentunya keenam narasumber tersebut melalui tahapan proses adopsi inovasi hanya saja tahapannya berbeda. seperti yang terjadi pada sekolah-sekolah yang peneliti wawancarai bahwa mereka telah mengetahui bank sampah ini karena program Adiwiyata sehingga langsung pada tahapan putusan karena ingin mengetahui lebih jelas seperti apa program kegiatan yang dilakukan Bank Sampah Barangbang.

\section{Proses Komunikasi Pada Inovasi Bank Sampah Sebagai Komunikasi Perubahan Sosial}

Mengubah kebiasaan dan paradigma masyarakat tentang sampah, diperlukan pemberian edukasi dan informasi mengenai manfaat dalam pengelolaan sampah sehingga diharapkan efektif dalam meningkatkan partisipasi untuk terlibat dalam penanganan sampah. Perubahan sosial terjadi dalam tiga langkah berurutan, pertama Invensi yaitu proses pengenalan mengenai bank sampah, kedua Difusi yaitu bagaimana mengkomunikasikan ide atau gagasan baru terkait pengelolaan sampah kepada anggota sistem sosial, ketiga Konsekuensi yaitu perubahan-perubahan yang terjadi bila menggunakan ide baru dan konsekuensi atas dampak tertentu bila terjadi penolakan ide baru (Rogers, 2003). Dalam proses sosial, komunikasi menjadi suatu cara dalam melakukan sebuah perubahan sosial. Adanya ajakan melalui persuasif akan mempengaruhi nilai budaya untuk berorientasi ke masa depan, sehingga setiap individu akan mempunyai motivasi untuk berkarya, berinovasi, bersikap hemat untuk menabung, disiplin, yang sangat berperan dalam modernisasi. Perubahan yang terjadi ketika dilihat dari aspek sosial, ekonomi dan lingkungan dengan adanya program bank sampah sebagai komunikasi perubahan sosial:

Tabel. 2 Perubahan aspek sosial, ekonomi dan lingkungan

\begin{tabular}{|c|c|c|}
\hline Aspek & Sebelum Program & Setelah Program \\
\hline Sosial & $\begin{array}{l}\text { 1. Tidak ada lembaga yang } \\
\text { bergerak dalam pengelolaan } \\
\text { sampah } \\
\text { 2. } \text { Belum ada } \\
\text { keahlian/keterampilan dalam } \\
\text { pengelolaan sampah } \\
\text { 3. Perilaku membuang sampah } \\
\text { sembarangan }\end{array}$ & $\begin{array}{l}\text { 1. Lahir kelembagaan bank sampah } \\
\text { barangbang } \\
\text { 2. Adanya peningkatan } \\
\text { pengetahuan dan } \\
\text { keterampilan dalam } \\
\text { pengelolaan sampah } \\
\text { 3. Masyarakat dapat memilah } \\
\text { sampah organik dan anorganik, } \\
\text { sampah ditabungkan di bank } \\
\text { Sampah }\end{array}$ \\
\hline Ekonomi & $\begin{array}{l}\text { 1. Belum memiliki aset sarana dan } \\
\text { prasarana pengelolaan sampah } \\
\text { 2. Kebanyakan ibu-ibu di } \\
\text { Kelurahan Muara Ciujung } \\
\text { Timur hanya Ibu Rumah } \\
\text { Tangga Sehingga tidak memiliki } \\
\text { penghasilan }\end{array}$ & $\begin{array}{l}\text { 1. Memiliki sarana dan prasarana } \\
\text { pengelolaan sampah } \\
\text { 2. Penghasilan meningkat } 20 \%-30 \%\end{array}$ \\
\hline
\end{tabular}




\begin{tabular}{l|l|l}
\hline Lingkungan & $\begin{array}{l}\text { 1. Lahan tidur belum } \\
\text { termanfaatkan }\end{array}$ & $\begin{array}{l}\text { 1. Pemanfaatan lahan tidur menjadi } \\
\text { lahan produktif untuk bank sampah }\end{array}$ \\
& $\begin{array}{l}\text { 2. Belum ada pemanfaatan } \\
\text { sampah organik dan anorganik }\end{array}$ & $\begin{array}{l}\text { 2. Sampah organik diolah menjadi } \\
\text { pupuk dan sampah anorganik diolah } \\
\text { menjadi kerajinan }\end{array}$ \\
& $\begin{array}{l}\text { 3. Sampah menumpuk di } \\
\text { sekitaran daerah aliran sungai }\end{array}$ & $\begin{array}{l}\text { 3. Sampah dapat berkurang sekitar 5\% } \\
\text { perhari }\end{array}$ \\
& $\begin{array}{l}\text { Muara Ciujung Timur dan } \\
\text { belakang rumah }\end{array}$ & \\
\hline
\end{tabular}

Sumber Data: Olahan Peneliti

\section{KESIMPULAN}

Keikutsertaan masyarakat dalam isu penyelesaian masalah sampah sangat diharapkan saat ini, karena tingginya volume sampah yang tidak tertangani/terangkut ke tempat pembuangan akhir akan berdampak balik pada lingkungan sekitar kita. Hal kecil yang sangat berdampak seperti membuat program bank sampah dirasakan manfaatnya baik kepada masyarakat itu sendiri maupun lingkungan. Pengelolaan sampah melalui pemberdayaan masyarakat juga akan mendorong pada sistem-sistem sosial masyarakat, seperti inovasi yang diciptakan pengurus Bank Sampah Barangbang mengajak masyarakat yang awalnya tidak melihat sampah sebagai hal yang berguna menjadi sesuatu bernilai baik secara kegunaan maupun pemasukan ekonomi. Proses inovasi tersebut semata-mata tidak hanya mengajak masyarakat untuk sadar, melainkan adanya tahapan difusi inovasi yang diterapkan seperti pemberian pengetahuan, ajakan, keputusan, dilakukan hingga dirasakan manfaatnya. Sehingga paradigm diawal berubah ketika inovasi yang diberikan diterima, diadopsi dan pada akhirnya terdapat perubahan sosial dimasyarakat.

\section{DAFTAR PUSTAKA}

Ahmad, R. (2016). Difusi Inovasi dalam Meningkatkan Partisipasi Masyarakat akan Kelestarian Lingkungan. Jurnal Sosietas Pendidikan Sosiologi, 6(2).

BAPPEDA. (2014). Rencana Pembangunan Jangka Menengah Daerah Kabupaten Lebak 20142019. Lebak: BAPPEDA.

BPS. (2018). Statistik Lingkungan Hidup Indonesia. Jakarta: Badan Pusat Statistik Indonesia.

Bungin, B. (2008). Sosiologi Komunikasi. Jakarta: Kencana.

Fahrudin, A. (2012). Pemberdayaan, Partisipasi dan Penguatan Kapasitas Masyarakat. Bandung: Humaniora.

Fatah, D. (2019, Juli 7). Wow Indonesia Produksi 64 Juta Ton sampah Per Tahun. Retrieved from Indopos.co.id: https://indopos.co.id/read/2019/07/07/180601/wowindonesia-produksi-64-juta-ton-sampah-per-tahun

Febriana, K. A., \& Setiawan, Y. B. (2016). Komunikasi dalam difusi inovasi Kerajinan Enceng Gondok Di Desa Tuntang Kabupaten Semarang. Jurnal The Messeger, 8(1) 17-26.

KLH. (2012). Buku Profil Bank Sampah Indonesia Tahun 2012. Jakarta: Deputi Pengelolaan Sampah Kementerian Lingkungan Hidup. 
Mardikanto, T. (2014). CSR (Corporate Social Responsibility) (Tanggung Jawab Sosial Korporasi). Bandung: Alfabeta.

Miles, M., Huberman, A., \& Saldana, J. (2014). Qualitative Data Analysis, A Methods Sourcebook, Edition 3 Terjemahan Tjetjep Rohindi Rohidi. Jakarta: UI Press.

Nasution, Z. (2002). Komunikasi Pembangunan: Pengenalan Teori dan Penerapannya. Jakarta: PT. Raja Grafindo Persada.

Purwanto. (2019). Pengelolaan "Bank Sampah" Berbasis Masyarakat Sebagai Alternatif Meningkatkan Ekonomi Warga RT 004/RW 009, Cikarang Utara Bekasi. Academics in Action Journal, 1(1) 27-37.

Rogers, E. M. (2003). Diffusion On Innovation 5th Edition. New York: Free Press.

Satori, D., \& Komariah, A. (2010). Metodologi Penelitian Kualitatif. Bandung: Alfabeta.

Satriani, I., Muljono, P., \& Lumintan, R. (2011). Komunikasi Partisipatif dalam Pos Pemberdayaan Keluarga. Jurnal Komunikasi Pembangunan, 9(1) 17-27.

Shahreza, M. (2018, Januari 1). Implementasi Teori Difusi Inovasi pada Gerakan Bank Sampah. Retrieved from Researchgate.net: https://www.researchgate.net/publication/325959864

Sucahya, M., \& Surahman, S. (2017). Difusi Inovasi Program Bank Sampah (Model Difusi Inovasi Pemberdayaan Masyarakat Dalam Pengelolaan Bank Sampah Alam Lestari Di Kota Serang Prov. Banten). Jurnal Ilmu Komunikasi, 8(1) 63-79.

Sulistyani, \& Teguh, A. (2004). Kemitraan dan Model-Model Pemberdayaan Masyarakat. Yogyakarta: Gava Media. 